\title{
Z dziejów „Buntu Młodych” i „Polityki”. Listy Aleksandra i Adolfa Marii Bocheńskich do Stanisława Łosia (1932-1939)
}

Zarys treści: Bracia Adolf Maria (1909-1944) i Aleksander Bocheńscy (1904-2001) należeli do najbliższych współpracowników Jerzego Giedroycia w okresie międzywojennym. Brali udział w redagowaniu „Buntu Młodych” (1931-1937) i „Polityki” (1937-1939) oraz w tworzeniu linii politycznej obu pism. Listy kierowane przez nich do Jana Stanisława Łosia (1890-1974), konserwatysty i byłego dyplomaty, pochodzą z pierwszego okresu istnienia „Buntu Młodych” - lat 1932-1933 i kluczowego dla okresu międzywojennego roku 1938. Korespondencja dotyczy przede wszystkim stosunku redakcji do polityki wewnętrznej i zewnętrznej II Rzeczypospolitej, w tym do polityki zagranicznej i narodowościowej.

Slowa kluczowe: Jerzy Giedroyc, konserwatyzm, polityka narodowościowa, prometeizm, stosunki polsko-ukraińskie

Key words: conservatism, ethnic politics, Prometheanism, Polish-Ukrainian relations

Historia pism redagowanych przez Jerzego Giedroycia w okresie międzywojennym już od dłuższego czasu cieszy się zainteresowaniem badaczy i wciąż ukazują się prace zgłębiające nowe aspekty tego zagadnienia ${ }^{1}$. Badanie poglądów politycznych Jerzego Giedroycia nie jest zadaniem łatwym, tym bardziej iż sam definiował się jako „zwierzę polityczne”, a jego działalność miała wymiar ściśle praktyczny, miała prowadzić do osiągnięcia pewnych, wytyczonych wcześniej celów, a nie reprezentować poglądy i myśl polityczną jakiejś konkretnej grupy. Jak wspominano wielokrotnie poważnym utrudnieniem w badaniach poglądów politycznych Jerzego Giedroycia, zarówno w okresie wcześniejszym, jak i późniejszym, jest fakt, że pozostawił po

\footnotetext{
${ }^{1}$ Por. m.in.: A. Micewski, W cieniu marszałka Piłsudskiego, Warszawa 1968; M. Król, Style politycznego myślenia. Wokół Buntu Młodych i Polityki, Paryż 1979; R. Habielski, Dokąd nam iść wypada? Jerzy Giedroyc od „Buntu Młodych” do „Kultury”, Warszawa 2006; R. Tomczyk, Myśl Mocarstwowa. Z dziejów młodego pokolenia II Rzeczypospolitej, Szczecin 2008.
} 
sobie bardzo nieliczne teksty, był właściwie redaktorem niepiszącym. $Z$ tego powodu jedyną metodą, z której mogą korzystać badacze, jest dogłębna analiza i konfrontacja artykułów drukowanych w pismach, które redagował. Dla okresu powojennego praca ta jest znacznie ułatwiona dzięki bardzo obfitej, obustronnej korespondencji (Giedroyc zachowywał nie tylko otrzymane pisma, ale także kopie wysłanych listów) przechowywanej w Archiwum Instytutu Literackiego w Maisons-Laffitte, natomiast „dotkliwie daje się odczuć brak przedwojennej korespondencji Redaktora zachowanej w stanie szczątkowym"2. Dotychczas korzystano przede wszystkim z pojedynczych listów znajdujących się w zbiorach rękopisów Biblioteki Uniwersytetu Warszawskiego i większej partii listów będących w posiadaniu rodziny Bocheńskich.

$\mathrm{Z}$ tego punktu widzenia, nowym źródłem ${ }^{3}$, niewykorzystywanym dotychczas w badaniach nad dziejami „Buntu Młodych” i „Polityki”, jest grupa listów z lat 30. pisanych przez braci Bocheńskich, Adolfa Marię i Aleksandra ${ }^{5}$ oraz Jerzego Giedroycia, do Stanisława Łosia ${ }^{6}$. Listy te znajdują się w spuściźnie profesora Stanisława Łosia w Archiwum Państwowym w Lublinie ${ }^{7}$ i ukazują nie tylko sposób redagowania „Buntu Młodych” (1931-1937) i „Polityki” (1937-1939), ale także sposób, w jaki postrzegali te pisma i sprawy bieżące bracia Bocheńscy, bardzo bliscy w tym okresie współpracownicy Giedroycia ${ }^{8}$, doskonale orientujący się w meandrach polityki Redaktora. Ich opinie uzupełniają słowa Giedroycia i pozwalają sprecyzować niektóre wnioski dotyczące politycznej linii i zapatrywań redakcji. W korespondencji poruszane jest szerokie spektrum zagadnień, głównie dotyczących stosunków polsko-ukraińskich, gdyż była to dziedzina, w której specjalizował się Stanisław Łoś. Natomiast przynajmniej trzy wybrane zagadnienia należy krótko skomentować.

2 R. Habielski, op. cit., s. 6.

${ }^{3}$ Niektóre listy Jerzego Giedroycia do Stanisława Łosia cytował Tomasz Czarnota w swoim artykule o urzędniczej karierze redaktora „Buntu Młodych”, pominął jednak zupełnie ich znaczenie dla jego biografii politycznej (por. T. Czarnota, Jerzy Giedroyc jako funkcjonariusz państwowy - wzorowy urzędnik czy polityczny ryzykant?, „Dzieje Najnowsze” 2012, nr 2, s. 3-32).

${ }^{4}$ Adolf Maria Bocheński (1909-1944), pisarz, publicysta. Działacz Związku Akademickiego „Myśl Mocarstwowa”, redaktor i publicysta „Buntu Młodych” i „Polityki”. Walczył w kampanii wrześniowej 1939 r., a następnie w szeregach Brygady Podhalańskiej i Pułku Ułanów Karpackich, zginął pod Ankoną.

5 Aleksander Bocheński (1904-2001), publicysta, konserwatysta, m.in. w 1933 we władzach Zjednoczenia Zachowawczych Organizacji Politycznych. Współpracownik wielu tytułów prasowych prawicowych i konserwatywnych. Od 1932 współpracownik „Buntu Młodych” i „Polityki”. Walczył w kampanii wrześniowej 1939 r., więziony przez NKWD, związany z Konfederacją Narodu, współpracował z RGO. Po 1945 pozostał w Polsce, związany ze Stowarzyszeniem PAX.

${ }^{6}$ Jan Stanisław Łoś (1890-1974), ziemianin, dyplomata, konserwatysta. W okresie międzywojennym m.in. pracownik MSZ i Ambasady RP w Londynie, od 1931 na emeryturze, zajmował się działalnością publicystyczną. Po 1945 r. pozostał w Polsce, był profesorem KUL. Patrz więcej: S. Łoś, Sprawa ukraińska. Wybór pism, oprac. M. Marszał, S. Wójtowicz, Kraków 2012, s. XIX-XX.

7 Por. m.in. S. Łoś, Sprawa ukraińska; P. Kusz, Jan Stanisław Łoś wobec kwestii ukraińskiej (1918-1939), Lublin 2010; M. Trojanowska, Archiwum Łosiów z Niemiec i jego znaczenie dla badań dziejów polskiej dyplomacji w okresie międzywojennym, „Miscellanea Historica Archivistica” 1999, t. IX, s. 71-84.

8 Por. J. Giedroyc, Autobiografia na cztery ręce, oprac. K. Pomian, Warszawa 2006, s. 71-74. 


\section{Stosunek do konserwatyzmu}

W okresie powojennym omawiając pisma, które redagował w okresie międzywojennym, Jerzy Giedroyc minimalizował ich konserwatywne oblicze i podkreślał przede wszystkim swą niezależność. Twierdził, iż oprócz Adolfa M. Bocheńskiego „Inni współpracownicy pisma, ze mną włącznie, bynajmniej się do konserwatyzmu nie poczuwali". Choć jednocześnie dodawał, że przyczyną jego zerwania z Rowmundem Piłsudskim ${ }^{9}$ było opuszczenie przez tego ostatniego środowisk neokonserwatywnych i przejście do lewicy piłsudczykowskiej. W świetle prezentowanych poniżej listów bardzo często słowa Giedroycia tracą swą jednoznaczność. I tak sformułowanie: „dla mnie cały ruch konserwatywny był ruchem nie bardzo poważnym” 10 można rozumieć jako powojenne odcinanie się od konserwatywnych korzeni albo - zgodnie ze słowami Aleksandra Bocheńskiego - jako krytykę konserwatystów współpracujących z piłsudczykami od czasów spotkania w Nieświeżu i konferencji w Dzikowie (IX 1927), a oskarżanych o „beznadziejny oportunizm”. Ze słów Bocheńskiego można wywnioskować, że celem „Buntu Młodych” w 1933 roku było stworzenie nowego środowiska zachowawczego, również współpracującego z BBWR („Celem ich jest tworzenie ideologii zachowawczej, a jednak mogącej objąć wszystkie sfery. (...) Będzie ono pracowało dla BBWR, ale takiego jakim mogło by być, a nie jest") ${ }^{11}$. Trudno, aby poglądy te nie były wówczas tożsame $\mathrm{z}$ wyznawanymi przez redaktora naczelnego pisma.

\section{Stosunek do prometeizmu}

Bardzo często w prowadzonej współcześnie debacie osoba Jerzego Giedroycia kojarzona jest $\mathrm{z}$ ruchem prometejskim. Jednakże jego działalność prometejska w okresie II RP ogranicza się do stworzenia i wydania pierwszego numeru pisma „Wschód-Orient”"12. Notatka Józefa Skarżyńskiego ${ }^{13}$, pracownika cywilnego Ekspozytury 2 Oddziału II Sztabu Głównego, z początku 1938 roku świadczy o tym, że Giedroyc nie miał powiązań organizacyjnych i nie był członkiem ruchu prometejskiego sensu stricto ${ }^{14}$. W świetle odnalezionych listów warto też odnotować pogardliwy stosunek do ruchu prometejskiego, jaki nieraz wyrażał Aleksander Bocheński. Pisząc o sztandarowym piśmie prometejskim, stwierdzał: „co do mnie

9 Rowmund Piłsudski (1903-1988), działacz polityczny i młodzieżowy, konserwatysta, założyciel Związku Akademickiego Myśli Mocarstwowej. W 1933 wydalony ze Związku. Po wojnie na emigracji, założyciel i długoletni przywódca Polskiego Ruchu Wolnościowego „Niepodległość i Demokracja”.

10 J. Giedroyc, op. cit., s. 57, 64; M. A. Supruniuk, Uporzadkować wspomnienia. Nieautoryzowane rozmowy z Jerzym Giedroyciem, Torun 2011, s. 41, 43.

11 Archiwum Państwowe w Lublinie [APL], Archiwum Łosiów z Niemiec, sygn. V/1, podt. 1, k. 125-128, 138-141. A. Bocheński do S. Łosia, 4 I 1933, 10 I 1933.

12 M. A. Supruniuk, op. cit., s. 31.

13 Józef Skarżyński (1899-1976), w latach 1929-1938 wykładowca w Oddziale II, urzędnik cywilny Ekspozytury 2, zajmował się sprawami prometejskimi, w 1938 roku brał udział w akcji dywersyjnej na Zaolziu.

14 P. Libera, Ocena polityczna grupy „Polityki” przez Oddział II Sztabu Głównego w 1938 r., „Zeszyty Historyczne” 2010, z. 171, s. 142-147. 
to nie uważam pisma w rodzaju «Biuletynu [Polsko-Ukraińskiego] ${ }^{15} »$ za celowe. Są one przeznaczone i dostępne tylko dla małej garstki specjalnie interesujących się tymi sprawami, którzy je i tak znają. Dobre to jest tylko jako forum gdzie można wszystko pisać, ale zasadniczo pisma finansowane przez rząd to nonsens o ile mają być niezależne myślowo ${ }^{16}$ ". Z kolei określając młodych secesjonistów Stronnictwa Narodowego i powód ich zerwania z endecją, twierdził: „Są dopiero w stadium marzeń prometejskich, ale któż z nas przez te choroby dziecinne nie przechodził" ${ }^{17}$.

Również Giedroyc, choć korzystał z wiedzy i doświadczenia Włodzimierza Bączkowskiego ${ }^{18}$, nie wyrażał się o nim z uznaniem (ten „poczciwy Bączkowski” ${ }^{19}$ ). Natomiast zaskakujące słowa poświęca Giedroyc swoim kontaktom z Tadeuszem Schaetzelem: „W ogóle ostatnio są bardzo serdeczne między nim a «Buntem [Młodych]» stosunki, tak że zaczyna się mówić (to do wyłącznej wiadomości Pana) o oddaniu «Biuletynu [Polsko-Ukraińskiego]» mnie by wychodził jako dodatek do «Buntu [Młodych]». Taka nasza «Pologne Litteraire» przy «Wiadomościach Literackich»" 20 . Informacja ta nie znajduje poparcia w innych materiałach źródłowych, świadczy jednak o bardzo bliskich kontaktach Giedroycia ze sferami prometejskimi. Dotychczasowe badania wskazują, że w okresie 1918-1939 Giedroyc był pod wpływem myśli prometejskiej, ale nie był działaczem ruchu prometejskiego.

\section{Niezależność finansowa}

Swoich kontaktów z działaczami ruchu prometejskiego i pracownikami wywiadu Giedroyc nigdy nie ukrywał ${ }^{21}$. Natomiast o ich intensywności świadczą fragmenty odnalezionych listów. Wybierając się do S. Łosia, pisał: „Gdyby to Panu konweniowało to mógłbym przywieźć z sobą kpt. E[dmunda] Charaszkiewicza ${ }^{22}$ (prawa ręka Schaetzla ${ }^{23}$, spec od spraw ukraińskich, odgrywa dość dużą rolę

15 „Biuletyn Polsko-Ukraiński” (1932-1938), pismo prometejskie wydawane ze środków finansowych Ekspozytury 2 Oddziału II Sztabu Głównego.

16 APL, Archiwum Łosiów z Niemiec, sygn. V/1, podt. 1. k. 178-179. A. Bocheński do S. Łosia, $17 \mathrm{~V} 1933$.

${ }_{17}$ Ibidem, sygn. 463, k. 7. A. Bocheński do S. Łosia, 4 XII 1938.

18 Włodzimierz Bączkowski (1905-2000), publicysta i działacz prometejski. Współpracował z Ekspozyturą 2 Oddziału II Sztabu Generalnego, Instytutem Wschodnim, twórca Orientalistycznego Koła Młodych (1928), redaktor „Wschodu” (1930-1939), założyciel i redaktor „Biuletynu Polsko-Ukraińskiego” (1932-1938) oraz „Myśli Polskiej” (1935-1939), od 1939 w Oddziale II Naczelnego Wodza, później na Bliskim Wschodzie w Ekspozyturze Oddziału II NW, związany z Centrum Informacji na Bliskim Wschodzie i Akcją Kontynentalną, od 1955 r. w USA, do 1971 r. pracował w Bibliotece Kongresu.

19 APL, Archiwum Łosiów z Niemiec, sygn. 456, k. 24. J. Giedroyc do S. Łosia, 31 VIII 193[3].

20 Ibidem, k. 35. J. Giedroyc do S. Łosia, 14 X 193[5].

${ }^{21}$ Np. J. Giedroyc, op. cit., s. 29-30, 41.

${ }^{22}$ Edmund Charaszkiewicz (1895-1975), ppłk, w 1. 1928-1939 szef Ekspozytury 2 Oddziału II Sztabu Głównego [SG], w której skoncentrowana była akcja prometejska, szczególnie po $1930 \mathrm{r}$.

23 Tadeusz Schaetzel (1891-1971), m.in. attaché wojskowy w Konstantynopolu (1924-1926), szef Oddziału II SG (1926-1929), kierownik Wydziału Wschodniego MSZ, a następnie wicedyrektor 
w polityce mniejszościowej) ewent[ualnie] por. Niezbrzyckiego ${ }^{24}$ ze Sztabu Głównego również specjalistę w tej dziedzinie, kandydata w najbliższej przyszłości na szefa biura pers[onalnego] w MSZ. (...) Proszę mi więc zawiadomić czy któregoś z tych Panów chciałby Pan widzieć, a w takim razie załatwiłbym to z przyjemnością, gdyż jestem z nimi w dosyć dobrych stosunkach" 25 . Z kolei proponując spotkanie w Warszawie, dodawał: „(...) prosiłbym o podanie wcześniej terminu przyjazdu Pana do Warszawy, by móc ustalić konferencję ze światowładnymi porucznikami. Proponuję konferencję: I/ p. Janina Hołówkowa ${ }^{26}$ i kpt. Charaszkiewicz, 2/ por. Jerzy Niezbrzycki i kpt. Drymmer"27. Dzięki kontaktom z Niezbrzyckim udało mu się ulokować Ksawerego Pruszyńskiego ${ }^{28}$ w Kijowie: „Spodziewam się od października bardzo sensacyjnych materiałów dotyczących Ukrainy Sowieckiej, gdyż udało mi się ulokować Ksawerego Pruszyńskiego w Kijowie na jakie 2-3 miesiące z możnością poruszania się po terenie. Przypuszczam, że zbierze ciekawe obserwacje no i skompletuje bibliotekę Buntu. W razie jeżeli miałby Pan do niego jakie polecenia to proszę przesłać list do niego na moje ręce, a ja mu prześlę przez kurierkę, gdyż normalną pocztą jest gwarancja przeczytania listu stuprocentowa" ${ }^{29}$.

O niezależności „Buntu Młodych” i „Polityki” wspominał wielokrotnie Giedroyc i bracia Bocheńscy, Aleksander w cytowanych powyżej listach, a także Adolf w liście do Łosia: „Zdaje się, że trochę przesadnie ocenia Pan związki naszej grupy z ulicą Wierzbową. (...) pochlebiamy sobie, iż nie jesteśmy ani uzależnieni od [pałacu] Bruhlowskiego ${ }^{30}$ ani nawet zbyt pożądani jako zwolennicy"31. Informacje te wydaje się potwierdzać cytowana wcześniej notatka, z której wynika, że do 1938 roku pismo nie otrzymywało subwencji Oddziału II: „Wyraźna przewaga plusów nad minusami, a przede wszystkim twórczy charakter prac grupy nakazuje podtrzymać tę grupę zarówno moralnie, jak i finansowo"32. Z powodu braków w dokumentacji można formułować jedynie bardzo ostrożne wnioski i stwierdzić, że przynajmniej w okresie od kwietnia do września 1939 roku według tajnego rozdzielnika Wydziału Wschodniego MSZ „Polityka” otrzy-

Departamentu Politycznego MSZ (1931-1935). Faktyczny kierownik akcji prometejskiej w okresie 1925-1935.

${ }^{24}$ Jerzy Niezbrzycki (1902-1968), m.in. publicysta i pracownik Oddziału II SG, szef referatu Wschód (1932-1939).

25 APL, Archiwum Łosiów z Niemiec, sygn. V/1, podt. 1. k. 218. J. Giedroyc do S. Łosia, 16 VI 193[3].

${ }^{26}$ Janina Hołówko, wdowa po Tadeuszu Hołówce (1889-1931).

27 APL, Archiwum Łosiów z Niemiec, sygn. 456, k. 16. J. Giedroyc do S. Łosia, 22 VI 193[3].

${ }^{28}$ Ksawery Pruszyński (1907-1950), dziennikarz, publicysta, członek „Myśli Mocarstwowej”. Rozpoczął stałą współpracę ze „Słowem” i przeniósł się do Wilna w 1932 r. W Kijowie przebywał jesienią $1933 \mathrm{r}$.

29 APL, Archiwum Łosiów z Niemiec, sygn. 456, k. 24. J. Giedroyc do S. Łosia, 31 VIII 193[3].

${ }^{30} \mathrm{~W}$ okresie II RP przy placu Marszałka Piłsudskiego róg Wierzbowej w pałacu Bruhla mieściła się siedziba MSZ.

${ }^{31}$ APL, Archiwum Łosiów z Niemiec, sygn. 463, k. 9. A. M. Bocheński do S. Łosia, 31 XI 193[8].

32 P. Libera, op. cit. 
mywała stałą, choć za każdym razem określaną jako „nadzwyczajną” dotację w wysokości $500 \mathrm{zl} \mathrm{miesięcznie}{ }^{33}$.

Dotychczas udało się odnaleźć 12 listów Aleksandra i Adolfa Marii Bocheńskich oraz 38 listów Jerzego Giedroycia skierowanych do Stanisława Łosia w okresie od 1929 do 1938 roku $^{34}$. Poniżej prezentowane są jedynie wybrane listy braci Bocheńskich do Stanisława Łosia. W wyborze pominięto dwa znacznie krótsze i mniej interesujące pod względem treści. Listy publikowane są bez żadnych skrótów, teksty opatrzono koniecznymi komentarzami, uwspółcześniono pisownię, milcząco poprawiono ewidentne literówki i braki znaków interpunkcyjnych, ingerencje redakcyjne zaznaczono w klamrach.

33 Archiwum Akt Nowych, Ministerstwo Spraw Zagranicznych, sygn. 5273, k. 2, 35, 85, 117, 214 , 230. Budżet Wydziału Wschodniego MSZ, IV-IX 1939.

34 Piszący te słowa pracuje nad edycją całego kompletu tych listów. 


\section{Adolf Bocheński do Stanisława Łosia, 14 VII 193[2].}

Ponikwa, dnia 14 VII 193[2]

Wielce Łaskawy Panie,

Ucieszyłem się niezmiernie widząc, iż artykuł mój w „Drodze”35 zainteresował Go i z góry się cieszę na wizytę w Niemcach ${ }^{36}$, które posiadają już wyrobioną opinię tak wysoko pod różnymi względami stojącej rezydencji. Pseudonim mój „Franciszek Lansdorff", którego zresztą użyłem po raz pierwszy, wywołał pewne nieporozumienie. Widzę bowiem, iż bierze mnie Pan za warszawianina, podczas gdy w rzeczywistości jestem najautentyczniejszym wschodnio-galicjaninem i młodszym bratem Aleksandra Bocheńskiego, który, o ile się nie mylę korespondował z Panem przez pewien czas.

Fakt zainteresowania się Pana moim artykułem ucieszył mnie zaś także ze względu na niezwykle wysoki poziom wszystkich Jego publikacji i, począwszy od studiów Januszowskiego w „Przeglądzie” 37 po prześwietną "Reformę konstytucji" ${ }^{38}$ aż do ostatnich publikacji ukraińskich. Od dawna też przyznam się, iż uważałem przez Pana za fenomen pewnego rodzaju, oczywiście w znaczeniu dodatnim. W Polsce bowiem jest rzeczą niesłychanie rzadką, by ktoś z beau monde'u naprawdę energicznie zajmował się polityką i publicystyką polityczną, a jeszcze rzadsze, by zajmowanie się to stało na naprawdę wysokim poziomie. $Z$ tego punktu widzenia sądziłem zawsze, iż działalność Pana przypomina raczej angielskie jak polskie wzory. Jeżeli pod tym względem coś się radykalnie nie zmieni w naszym high-life'ie, to prawdopodobnie utraci on najzupełniej autorytet polityczny, który w pewnej mierze jeszcze dziś posiada i który stanowi niezawodnie dość dużą siłę polityczną.

Byłbym specjalnie uradowany, gdybym mógł dowiedzieć się, co Pan sądzi o naczelnej tezie mojego studium a mianowicie o ustosunkowaniu do Rosji i Niemiec jako o zasadniczej różnicy między zachowawczymi a narodowymi demokratami. Dotychczas konsultowani przeze mnie zachowawcy z młodszej generacji, a mia-

${ }^{35}$ F. Lansdorff [Adolf Maria Bocheński], Zagadnienie prawicy w Polsce I i II, „Droga” 1932, nr 6, s. 566-579, nr 7-8, s. 710-725.

${ }^{36}$ Niemce, majątek w pow. lubartowskim, który wniosła w wianie żona S. Łosia, Marta Łoś z Budnych (1898-1969), por. E. Wierzbicka, Marta z Budnych Łosiowa (1898-1969) i jej dwór w Niemcach w latach 1918-1944, [w:] Ziemiaństwo na Lubelszczyźnie III, Panie z dworów i pałaców, t. 1, red. H. Łaszkiewicz, Lublin 2007, s. 340-360.

37 Stanisław Łoś opublikował pod pseudonimem Andrzej Januszewski dwuczęściowe studium Polityka Wielkiej Brytanii na łamach „Przeglądu Współczesnego” (1928, t. XXVII, nr 79 (listopad), s. 177-204, nr 80 (grudzień), s. 413-434).

38 S. Łoś, Reforma Konstytucji, „Przegląd Współczesny” 1931, t. XXXVII, nr 108 (kwiecień), s. 81-98. 
nowicie Piotr Borkowski ${ }^{39}$, Mackiewicz ${ }^{40}$, Juliusz Tarnowski ${ }^{41}$ i i[nni]. Twierdzą, iż moja opinia jest fałszywa, lecz nic pozytywnego przeciwstawić jej nie mogą. Cieszyłbym się więc, gdybym mógł usłyszeć zdanie tak wybitnego i niezależnego działacza zachowawczego jak Pan. Na łamach „Drogi” wystrzegałem się wyciągania wszelkich konkluzji politycznych z moich rozważań, lecz obecnie opracowuję drugą część pierwszej części mojej rozprawy i rozszerzam drugą część. Pragnąłbym wydać całość jako broszurę u Hoesicka ${ }^{42}$, ale nie wiem, czy mnie się to uda ${ }^{43}$.

Jeżeli wyjdziemy z założenia, iż zasadniczą różnicą między narodową demokracją a zachowawcami są zagadnienia racji stanu, to musimy przyjść do przekonania, iż różnice te odnoszą się do przyszłości, a nie do teraźniejszości, a to z powodu niemożności praktycznej realizacji w dzisiejszych warunkach tego programu, który byłby sympatyczny zachowawcom. Stąd zdaje się wynikać twierdzenie, iż nigdy zachowawcy nie będą stać tak blisko narodowych demokratów jak w chwili obecnej. Dochodzę zresztą do przekonania, także na podstawie analizy poszczególnych zagadnień (także ukraińskiego, sic!) związanych z naszą racją stanu, lecz niestety widzę zupełną nieeuklidesowość tych rozważań wobec protestu prawie wszystkich konserwatystów.

Na razie nie pozostaje mnie nic innego, jak podziękować Panu za tak uprzejme zaproszenie, które, jak mam nadzieję, odnosić się będzie do mnie w równej mierze jak do owego „Franciszka Lansdorffa” (Lansdorff jest to nasz przydomek rodzinny z XV jeszcze wieku, o którym między innymi wspomina i Niesiecki ${ }^{44}$ ). Z największą przyjemnością skorzystam z tego zaproszenia, a tym bardziej, iż miałem wybrać się już od dawna do Lublina w celu wydobycia niektórych dokumentów genealogicznych od wuja mego Ojca ${ }^{45}$, biskupa Jełowickiego ${ }^{46}$.

39 Piotr Dunin-Borkowski (1890-1949), ziemianin, polityk konserwatywny, działacz Ludowej Grupy Konserwatywnej, założyciel Klubu Zachowawczego Pracy Państwowej, wojewoda lwowski (1927-1928), wojewoda poznański (1928-1929), współpracownik „Buntu Młodych” i „Polityki”.

40 Stanisław Cat-Mackiewicz (1896-1966), publicysta polityczny, konserwatysta, monarchista, założyciel, wydawca i redaktor naczelny „Słowa” wileńskiego (1922-1939). Poseł na Sejm II i III kadencji 1928-1935 z ramienia BBWR. W 1939 krótko więziony w Berezie Kartuskiej. Na emigracji premier rządu RP na Uchodźstwie (1954-1955), od 1955 współpracownik Departamentu I Komitetu do spraw Bezpieczeństwa Publicznego, w 1956 wrócił do Polski.

${ }^{41}$ Prawdopodobnie Juliusz Tarnowski (1901-1940), syn Juliusza Tarnowskiego, dziedzica Byszewa, i Heleny z Babeckich. Od stycznia 1927 r. pełnił funkcję sekretarza w warszawskim zarządzie okręgowym POZPP. Brał udział w kampanii wrześniowej w stopniu porucznika kawalerii 3 pułku ułanów. Wzięty do niewoli sowieckiej, był internowany w Kozielsku. Prawdopodobnie zginął w 1940 roku w Katyniu.

${ }^{42}$ Wydawnictwo Ferdynanda Hoesicka.

${ }^{43}$ Książka Między Niemcami a Rosją ukazała się ostatecznie w 1937 roku jako wydawnictwo „Polityki”, opublikowane przez Księgarnię F. Hoesicka w Warszawie.

${ }^{44}$ „Jan Lansdorff Bocheński pisał się z Chełmińskiem województwem na elekcją Władysława IV” (Herbarz Polski Kaspra Niesieckiego SJ powiększony dodatkami z późniejszych autorów, rękopisów, dowodów urzędowych i wydany przez Jana Nep. Bobrowicza, t. II, Lipsk 1839, s. 182).

45 Marian Łoś (1856-1940).

46 Adolf Józef Jełowicki (1863-1937), biskup rzymskokatolicki, biskup pomocniczy lubelski (1918-1937). 
Proszę przyjąć wyrazy wysokiego poważania

Franciszek Lansdorff vulgo

[odręcznie:] Adolf M. Bocheński

APL, Archiwum Łosiów $z$ Niemiec, sygn. 456, k. $6 r$-v.

\section{Aleksander Bocheński do Stanisława Łosia, 4 I 1933.}

Ponikwa, 4 I [19]33

Wielce Laskawy Panie, Szkoda to wielka, że Pan stale nie mieszka we Lwowie. Z okazji procesu terrorystó $^{47}$ poseł Hausner ${ }^{48}$ zbierał podpisy na prośbę do Prezydenta ${ }^{49}$ o ułaskawienie. Pomyślał o tym dopiero o $12 \mathrm{w}$ nocy (wyrok miał być wykonany o świcie ${ }^{50}$ ) i zaczął zbierać podpisy. Podpisali Piotr Borkowski, Wojciech Gołuchowski ${ }^{51}$, Prof[esor] Moraczewski ${ }^{52}$, Red[aktor] Laskownicki ${ }^{53}$, wszyscy zerwani z łóżek ad hoc. Wówczas pomyślał $\mathrm{H}$ [ausner] o Drojanowskim ${ }^{54}$, prezydencie miasta. Drojanowski prosił o 20 minut celem zebrania podpisów B [ezpartyjnego] B[loku] [Współpracy z Rządem], tymczasem zatelefonował do Warszawy, skąd odpowiedziano mu, że taka petycja

47 Proces przed sądem doraźnym we Lwowie 17 XII 1932-22 XII 1932 przeciwko członkom OUN oskarżonym o napad na urząd pocztowy w Gródku Jagiellońskim (30 XI 1932), w którym zginęły 3 osoby i 1 została ciężko ranna. Aresztowano czterech członków OUN: Dmytro Danyłyszyna (1907-1932), Wasyla Biłasa (1911-1932), Mariana Żurakiwśkiego (1907-1932) i Zenona Kossaka (1907-1939). Po aresztowaniu W. Biłas przyznał się do zabójstwa Tadeusza Hołówki w Truskawcu (29 VIII 1931). Danyłyszyn, Biłas i Żurakiwśkyj zostali skazani na karę śmierci, Kossaka przekazano sądowi przysięgłych. W stosunku do Żurakiwśkiego prezydent Mościcki zastosował prawo łaski i zamienił karę śmierci na 15 lat ciężkiego więzienia (por. I. Werschler, $Z$ dziejów obozu belwederskiego. Tadeusz Hołówko, życie i działalność, Warszawa 1984, s. 323 i nast.).

48 Artur Hausner (1870-1941), polityk, socjalista, publicysta, poseł na Sejm Ustawodawczy i Sejm I i II kadencji 1922-1930.

49 Prezydentem RP w okresie 1926-1939 był prof. Ignacy Mościcki.

${ }^{50}$ Wyrok wykonano o świcie 23 XII $1932 \mathrm{r}$.

51 Wojciech Agenor Gołuchowski (1888-1960), polityk, konserwatysta, senator IV kadencji 1935-1938. Prezes Związku Ziemian Wschodniej Małopolski, wojewoda lwowski (1928-1930).

52 Wacław Moraczewski (1867-1950), dr medycyny, rektor Akademii Weterynaryjnej Medycyny we Lwowie.

${ }^{53}$ Bronisław Laskownicki (1866-1944), dziennikarz, od 1890 współpracownik „Dziennika Polskiego”, od 1896 „Słowa Polskiego”, w 1901 założyciel czasopisma „Wiek Nowy”, założyciel organu NKN "Gazety Polskiej” (1915). Redaktor naczelny i członek lwowskiego koncernu prasowego Prasa Nowa. Związany z obozem sanacji.

${ }^{54}$ Wacław Drojanowski (1896-1981), prezydent Lwowa (1931-1936). 
byłaby źle widziana, wobec czego odmówił podpisu. Zniechęcony Hausner poszedł spać i petycji nie posłał. Myślę, że gdyby ktoś energiczniejszy był we Lwowie, prośba jednak mogła być wysłana i zawierać podpisy ludzi ze wszystkich obozów. Bez względu na decyzję Prezydenta, taka prośba to byłby bardzo piękny gest polskiego społeczeństwa i trochę wzmocniłby stanowisko kół umiarkowanych Unda ${ }^{55}$, wobec radykałów poli[tycznych], którzy teraz, po wyroku, silnie bardzo podnieśli głowę.

Ogólna sytuacja w Państwie wskazuje jednak coraz słabszą postawę sympatii społeczeństwa do B [ezpartyjnego] B[loku] [Współpracy z Rządem], a raczej do grupy rządzącej. Nie tylko kryzys, ale bardziej jeszcze przeświadczenie, że ta grupa nikomu, pod żadnym pozorem dobrowolnie rządów nie odda, odwraca kraj od nich. Mowy Sławka ${ }^{56}$ w stronę społeczeństwa wywołują zdumienie. Sławek zachęca społeczeństwo do wstępowania do B[ezpartyjnego] B[loku] [Współpracy z Rządem], tymczasem struktura wewnętrzna B[ezpartyjnego] B[loku] [Współpracy z Rządem] jest taka, że każdy BB-k musi bezwzględnie być posłusznym pułkownikom. Na co im mądrych i uczciwych ludzi, jeśli mają ich zmieniać na niewolników, na to, aby być ślepo posłusznym, nie potrzeba wartościowych elementów, do których Sławek się zwraca, wystarczą urzędnicy, którzy muszą być w B [ezpartyjnym] B[loku] [Współpracy z Rządem], i stanowią jedyną jej podstawę, oczywiście nie z przekonania. W tym stanie rzeczy właściwie B[ezpartyjny] B[lok] [Współpracy z Rządem] nie opiera się na niczym, może jeszcze egzystować póki Marszałek będzie je popierał swoim autorytetem, ale wewnętrznie, B[ezpartyjny] B[lok] [Współpracy z Rządem] nie reprezentuje już prawie nic.

Ta sytuacja wymaga ustanowienia rewizji dotychczasowej polityki konserwatystów. Zachowawcy będą odpowiadać za politykę, która nie jest ich polityką, która ich doprowadziła do ruiny, a jednak którą w oczach kraju oni jedyni moralnie żyrują. Czy w ogóle konserwatyści coś znaczą i znaczyć będą, czy nie lepiej byłoby, aby myślący zachowawcy przyłączyli się [do] któregoś z istniejących obozów ideologicznych, gdzie są możliwości pracy, kiedyś przynajmniej, oto pytania, nad którymi często się zastanawiam.

Czy Pan zetknął się kiedyś z akcją Rowmunda Piłsudskiego. Temu młodemu człowiekowi można zarzucić wszystko prócz braku sprytu i wielkich ambicji. Zaraz po zamachu zorientował się w tym, że jeśli naród w tej czy innej formie nie będzie decydował o rządach, to będzie o nich decydować siłą. Zaczął tworzyć bojówki z przeświadczeniem, że kiedyś będą one dość silne, by wyemancypować się spod B[ezpartyjnego] B[loku] [Współpracy z Rządem]. Zebrał młodych konserwatystów, starając się mieć zarówno wielkie nazwiska i fortuny, jak i ludzi czynnych. Z ideologią było gorzej, propagował syndykalizm, i aneksję Prus Wsch[odnich]. To były dwa hasła, za pomocą których chciał zyskać ludzi, nie wiem, czy sam w nie wierzył. Nazwał to „Myślą Mocarstwową", co do mniejszości wysuwał program dość mętny. Sławek popierał to wszystko bardzo ostro, rząd to finansował nawet. Wkrótce wśród Mocarstwowców

${ }^{55}$ UNDO, Ukraińskie Zjednoczenie Narodowo-Demokratyczne, ukraińska partia polityczna w II RP (1925-1939).

56 Walery Sławek (1879-1939), ppłk, polityk, członek OB PPS, bliski współpracownik J. Piłsudskiego, szef BBWR (1927-1935), trzykrotny premier (1930, 1930-1931, 1935) i marszałek Sejmu (1938). 
pozostały tylko dwa odcienie: ideowców, którzy chcieli, aby konserwatyści mieli siłę i szli na masy, oraz łapserdaków, którzy ciągnęli różne zyski od rządu via Rowmund.

Wśród ideowców wybili się Ksawery Pruszyński i Giedroyć. Pruszyński pisywał $\mathrm{w}$ „Czasie” drobnym drukiem faits divers, na ostatniej stronie, przy czym wyrobił sobie doskonałe pióro. Kiedy jednak „czass” nie chciał drukować jego wstępnych art[ykułów] obraził się na Kraków, a ponieważ w sam raz nawinął się [Stanisław Cat] Mackiewicz, który obiecał mu [artykuły] wstępne, przeto przeniósł się do Wilna, gdzie pisuje w „Słowie”. Giedroyc był sekretarzem min[istra] rolnictwa Janty Połczyńskiego ${ }^{57}$ i kierował organizacją mocarstwową. Oni to obaj zrobili secesję ideową od Rowmunda i wydają pismo pt. „Bunt Młodych”. Celem ich jest tworzenie ideologii zachowawczej, a jednak mogącej objąć wszystkie sfery. Mają swoich ideowców jeszcze od Rowmunda, którzy są rzeczywiście ideowcami, gdyż choć klepią biedę, jednak za własne pieniądze wydają ten „Bunt Młodych”. Jest to jedyne pismo, które ma ambicje polityczne i ideologiczne, a nie jest zależne od żadnej grupy partyjnej, ani od rządu. Odcień jest lekko opozycyjny, a jednak nieendecki, jest w sprawach mniejszościowych takich przekonań, jak Pan i ja. Jest konserwatywne, a jednak ma entuzjazm i wiarę w swoje hasła, których brak naszym kanapistom. Ponieważ znałem osobiście Ks[awerego] Pruszyńskiego, zwrócił się on do mnie, żebym skarotował Pana na stałą współpracę w „Buncie [Młodych]”. Poza tym będą pisywać mój brat ${ }^{58}$ i Piotr Borkowski.

Nie chciałbym, żeby Pan mi miał za złe tej prośby, z tego powodu, że dotąd „Bunt [Młodych]" był nieznany i źle redagowany. Poczytność zależy dużo od piszących, teraz przy zmianie redakcji niewątpliwie zyska, a w każdym razie Pruszyński jest lepszy od Bobrzyńskiego ${ }^{59} \mathrm{i}$ kierunek pisma jest znacznie lepszy od „Naszej Przyszłości”“60. Będzie ono pracowało dla B[ezpartyjnego] B[loku] [Współpracy z Rządem], ale takiego, jakim mogłoby być, a nie jest. Pozwalam sobie w załączeniu posłać jeden $\mathrm{nr}$ „Buntu [Młodych]”. Jest on jeszcze bardzo słaby, ale Pruszyński pokazuje tu swój lwi pazur, mam wrażenie, że jest znacznie lepszy od [Stanisława Cata] Mackiewicza, chciałbym wiedzieć, czy i Pan podziela to przekonanie?

Łączę wyrazy wys[okiego] szacunku i poważania, Pani ${ }^{61}$ ręce całuję [Aleksander Bocheński]

\section{APL, Archiwum Łosiów z Niemiec, sygn. sygn. V/1, podt. 1, k. 125-128.}

${ }^{57}$ Leon Janta Połczyński (1867-1961), ziemianin i polityk, działacz Chrześcijańsko-Narodowego Stronnictwa Rolniczego. Minister rolnictwa (1930-1932), senator RP I i III kadencji 1922-1928, 1930-1935. Giedroyc był sekretarzem Janty Połczyńskiego w latach 1930-1932.

58 Adolf Maria Bocheński.

59 Jan Bobrzyński (1882-1951), syn historyka Michała Bobrzyńskiego (1849-1935), publicysta konserwatywny i polityk. Od 1926 sekretarz generalny Stronnictwa Prawicy Narodowej. Redaktor i wydawca miesięcznika „Nasza Przyszłość” (1930-1939). Zwolennik współpracy z sanacją, w 1934 powołał Związek Polskiej Myśli Państwowej. W czasie II wojny światowej w RGO.

60 „Nasza Przyszłość”, konserwatywny miesięcznik wydawany (1930-1939) przez Jana Bobrzyńskiego.

${ }^{61}$ Marta Łoś z Budnych (1898-1969). 


\title{
Aleksander Bocheński do Stanisława Łosia, 10 I 1933.
}

\author{
Ponikwa, 10 I [19]33
}

\section{Łaskawy Panie,}

dziękuję bardzo za list, który mnie zrobił wielką przyjemność, gdyż przekonałem się, że w zasadniczych sprawach jesteśmy tego samego zdania. To, co oburza w Galicji wsch [odniej], to nie wyrok lwowski, ale tryumf tego haniebnego systemu prowokacji, policji i bezmyślności, którym zastępujemy wszelką politykę. Tyczy to zwłaszcza zeznań Motyki ${ }^{62}$, który był niewątpliwie prowokatorem i zorganizował zamach na Hołówkę. Wyrok musiał być ostry, ale dzień po dniu mija i przepaść coraz większa dzieli nas od możliwości złagodzenia sprawy ukraińskiej. Na to potrzeba przede wszystkim uczciwego informowania społeczeństwa polskiego, a nie tej obłudnej gry, jaką nasza prasa prowadzi.

„Bunt Młodych” ma to dobrego, że można w nim drukować absolutnie wszystko, co się chce, oczywiście wówczas poziom pisma może być bardzo zły albo bardzo dobry, zależnie od tego, kto to drukuje. Giedroyć stara się, żeby to się kiedyś stało takim pismem zachowawczym jak „Myśl Narodowa"63 lub „Awangarda"64 są endeckie, „Przełom” ${ }^{65}$ radykalno-bebeckie itd., dlatego chciałbym, aby Pan, mój brat ${ }^{66}$, Piotr Borkowski i Chrząszczewski ${ }^{67} \mathrm{w}$ nim pisali. Im więcej będziemy w nim pisać, tym mniej będą pisać inni, jest to placówka wolna, którą z łatwością można opanować. Byłaby to pozycja konserwatywna, ale niemająca nic wspólnego z naszym konserwatyzmem oficjalnym p [anów], Wielowiejskiego ${ }^{68}$, St[anisława] Badeniego ${ }^{69}$, ks[ięcia]

${ }^{62}$ Mikołaj Motyka (1912-?), oskarżony o współudział w zamach na T. Hołówkę, świadek oskarżenia w procesie przeciwko OUN.

63 „Myśl Narodowa”, tygodnik wydawany w Warszawie (1921-1939), organ Narodowej Demokracji.

64 "Awangarda”, dwutygodnik wydawany w Poznaniu (1927-1933), poprzednio „Akademik” (1922-1926), od 1934 roku „Awangarda Państwa Narodowego” organ Związku Młodych Narodowców.

65 „Przełom”, tygodnik (1926-1935) wydawany w Warszawie przez Związek Naprawy Rzeczypospolitej.

66 Adolf Maria Bocheński.

67 Teodor Aleksander Trzaska-Chrząszczewski (1887-po 1957), publicysta. Referent w PRM (1918-1921) i w Wydziale Wschodnim MSZ (1921-1922), radca prawny w GUL (1922-1923), zastępca szefa Kancelarii Cywilnej Prezydenta RP (1923-1926), kierownik samodzielnego referatu państw bałtyckich w Wydziale Traktatowym MPiH (1927-1928). Następnie publicysta dla „Czasu”, „Kuriera Warszawskiego”, „Kuriera Polskiego”, od 1933 r. współpracował z „Buntem Młodych”. W 1939 nakładem „Polityki” ukazała się jego książka: Przypływy i odpływy demokracji, Warszawa 1939.

${ }^{68}$ Józef Wielowieyski (1879-1951), dyplomata, prawnik, konserwatysta, senator III kadencji z listy BBWR (1930-1935), wiceprzewodniczący Rady Naczelnej Organizacji Ziemiańskich (1930-1936), prezes Stronnictwa Chrześcijańsko-Rolniczego (1928-1939), wiceprezes Zjednoczenia Zachowawczych Organizacji Politycznych (1933-1939).

${ }_{69}$ Stanisław Badeni (1878-1943), polityk, konserwatysta, działacz Stronnictwa Prawicy Narodowej w Krakowie, członek Rady Nadzorczej Organizacji Ziemiańskich (od 1919), uczestnik Zjazdu w Dzikowie 
Radziwiłła $^{70}$ etc., którzy nie potrafili nic absolutnie uczynić, aby społeczeństwo w jakimkolwiek kierunku prowadzić. Beznadziejny oportunizm, uprawiany przez klub poselski ${ }^{71}$ i „Czas” ${ }^{2}$, doprowadzi do zupełnego zaprzepaszczenia możliwości, które teraz istnieją dla zgrupowania żywiołów poważnych w B[ezpartyjnym] B[loku] [Współpracy z Rządem]. Żywioły te prawdopodobnie, po upadku B[ezpartyjnego] B[loku] [Współpracy z Rządem] trafią znów, faute de mieux, do endecji, choć i endecja nie jest zbyt silną i u niej wewnątrz jest bardzo silna walka.

To, co Pan pisze o wyłącznym stanowisku pułkowników, którą zawdzięczają swojej woli panowania, jest nadzwyczaj trafna. Sądzę jednak, że prędzej czy później ta wola przejawi się i gdzie indziej, i tak czy inaczej opinia całego państwa będzie decydowała. Chciałbym bardzo, żeby na tę chwilę już był wykonany jakiś wysiłek intelektualny konserwatystów, w kierunku stworzenia programu. Dotąd twórczo pracowali tylko radykali, partyjnie tak czy inaczej zwący się, a konserwatyści byli tylko odbiorcami ich myśli i programów. Czy nie dałoby się zrobić odwrotnie, żebyśmy to kiedyś zaczęli mówić i myśleć, a żeby szerokie sfery inteligencji nas słuchały i przejęły nasze plany. Oczywiście to się nie stanie nigdy dopóki za konserwatystów są uważani nasi przywódcy obecni - kompletna bebecja nie tylko ideologicznie, ale i taktycznie. Koniecznym jest zdaje mi się postaranie się o przygotowanie terenu wśród inteligencji, o to nikt się nie stara, taka „Nasza Przyszłość” tego niestety nie zrobi, tylko toną w straszliwej powodzi grafomaństwa "Stańczyka"73, niektóre świetne artykuły, np., Pana, M[ariana] Zdziechowskiego ${ }^{74}$, Studnickiego ${ }^{75}$, Wierzbickiego ${ }^{76}$...

(1927), działacz BBWR (1928-1935), członek Zarządu i Rady Naczelnej Zjednoczenia Zachowawczych Organizacji Politycznych (od 1933), od 1937 współorganizator Stronnictwa Zachowawczego. Założyciel i Wydawca „Przeglądu Współczesnego” (1922-1939).

70 Janusz Radziwiłł (1880-1967), ziemianin, prawnik, polityk, konserwatysta. M.in. prezes Klubu Społeczno-Politycznego (1923-1926), uczestnik zjazdu w Dzikowie (1927), wiceprezes i prezes Stronnictwa Prawicy Narodowej (od 1926), poseł na Sejm II i III kadencji 1928-1935, senator IV kadencji 1935-1939, od 1937 w OZN i Stronnictwie Zachowawczym. Po wojnie represjonowany, pozostał w kraju.

${ }^{71}$ W III kadencji Sejmu (1930-1935) posłowie konserwatywni należeli do klubu poselskiego BBWR.

72 „Czas”, dziennik, organ konserwatystów krakowskich (1848-1939), od 1935 wydawany w Warszawie.

${ }^{73}$ Aluzja do konserwatywnego Stronnictwa Prawicy Narodowej, które było kontynuacją ugrupowania stańczyków krakowskich.

${ }^{74}$ Marian Zdziechowski (1861-1938), historyk idei i literatury, filolog, filozof, profesor i rektor USB.

75 Władysław Studnicki-Gizbert (1867-1953), polityk, ekonomista i publicysta. Zesłaniec, członek Tymczasowej Rady Stanu (1916-1917), naczelnik w Zarządzie Cywilnym Ziem Wschodnich (1919-1921), konsultant MPiH i MSZ, wykładowca Instytutu Nauk Handlowo-Gospodarczych w Wilnie i Szkoły Nauk Politycznych Instytutu Naukowo-Badawczego Europy Wschodniej w Wilnie. Znany przede wszystkim jako publicysta, początkowo związany z obozem socjalistycznym, następnie zwolennik opcji „proniemieckiej”.

${ }^{76}$ Andrzej Wierzbicki (1877-1961), działacz gospodarczy i polityczny, przedstawiciel kół reprezentujących wielki kapitał, m.in. członek Tymczasowej Rady Stanu (1916-1917), Komitetu Narodowego Polskiego w Paryżu i delegacji na konferencję pokojową w Paryżu (1919). Od 1919 współtwórca i dyrektor naczelny Centralnego Związku Polskiego Przemysłu, Górnictwa, Handlu i Finansów („Lewiatan”), od 1932 prezes zarządu Centralnego Związku Przemysłu Polskiego. 
reszta jest tak fatalnie na niskim poziomie, że wprost uniemożliwia czytanie przeciętnie wykształconemu czytelnikowi. Musimy koniecznie zerwać z literaturą „dla wyższych sfer o niższym poziomie umysłowym”, jak to powiedział Nowaczyński ${ }^{77}$, o ziemianach i postarać się o innych klientów.

Być może, że w drugiej połowie stycznia będę w Warszawie, czy Pan przypadkiem tam się nie wybiera, jeśli nie, to skorzystam $z$ dawnego łaskawego zaproszenia i po drodze zajadę do Niemiec, o czym telegraficznie poprzednio zawiadomię W. łaskawego Pana.

Łączę serdeczny uścisk dłoni i wyrazy wys[okiego] poważania, Pani ręce całuję [odr: Aleksander Bocheński]. APL, Archiwum Łosiów z Niemiec, sygn. V/1, podt. 1. k. 138-141.

\section{Aleksander Bocheński do Stanisława Łosia, 23 II 1933.}

Ponikwa, 23 II 1933

Wielce Szanowny Panie,

Niestety Giedroyć nie mógł przyjechać i nie wiem dotąd, jakie jest zdanie Pana co do „Buntu Młodych”, czy będzie można liczyć na współpracę Pana? Męczą mnie ciągle z Warszawy, żebym skarotował Pana na artykuł.

Przedostatni $\mathrm{n}$ [ume $] \mathrm{r}^{78}$ zrobił sporo hałasu, jakiś poseł z Ch[rześcijańskiej] $\mathrm{D}$ [emokracji ${ }^{79}$ czytał go na sejmie $^{80}$. Pismo to ma do siebie, że jest wydawane

77 Adolf Nowaczyński (1876-1944), publicysta, pisarz, działacz polityczny i społeczny. Związany z ND.

78 „Bunt Młodych” styczeń 1933, nr 35.

79 Wacław Bitner (1893-1981), adwokat i polityk. Działacz i członek władz naczelnych Chrześcijańskiej Demokracji (1919-1937), poseł na Sejm RP I, II i III kadencji (1922-1935). W okresie II wojny światowej kierownik Polskiej Katolickiej Agencji Prasowej w Nowym Jorku. Po 1945 wrócił do kraju, działał w Stronnictwie Pracy.

${ }^{80} \mathrm{Na} 83$ posiedzeniu Sejmu III kadencji, 9 III 1933, Wacław Bitner poseł ChD, w trakcie dyskusji nad preliminarzem budżetowym na r. 1933/1934 powiedział, zwracając się do posłów BBWR: „(...) gdy widzę to, co się dzieje w Polsce, gdy widzę te czyny i porównuję je z tym, co czytam, to staje przede mną dylemat: Czy p. Marszałek wyrzekł się swoich zasad, czy porwaliście je razem z prawem i Konstytucją? Widzimy to nie tylko my, widzi to wielu z Was. Oto czytamy, co pisze Wasza własna młodzież (...): «Czerwienimy się za Was, Panowie. Polska była synonimem wolności i bohaterstwa. Niegdyś we Francji, gdy mówiono o wielkości, mówiono o Polsce. Dziś, gdy się mówi o Polsce, mówi się z sarkazmem, ponieważ rządzący nie wyobrażają sobie polityki inaczej, jak kłamstwem, inaczej władzy, jak policjantem. Czerwienimy się za Was, Panowie. Nie wiemy, czy danym nam będzie czynem zaświadczyć, że prócz takiej Polski jest Polska tradycji, Polska wolność». Czy to wyszło tu spod pióra opozycji. Nie, to napisał - godna jest umieszczenia odwaga tego człowieka p. Bocheński, młody 
z pewnym rozmachem i idzie na massy, nie tylko na konserwę, jak dotąd cała nasza prasa prawicowa.

Teraz przygotowujemy ankietę w sprawie ukraińskiej, najpierw wśród Ukraińców, potem wśród Polaków, chcielibyśmy i w pierwszym rzędzie i Pana, ale też liczymy na artykuły $\mathrm{z}$ różnych dziedzin.

Łączę uścisk dłoni i wyrazy wys[okiego] poważania

[odręcznie:] Aleksander Bocheński

APL, Archiwum Łosiów z Niemiec, sygn. 463, s. k.

\section{Aleksander Bocheński do Stanisława Łosia, 7 III 1933.}

Ponikwa, dnia 7/3 1933

Szanowny Panie, Rzeczywiście Kedryn ${ }^{81}$ napisał swój artykuł bardzo jaskrawo ${ }^{82}$ (czytałem tylko obszerny cytat $\mathrm{w}$ „Czasie”83), ale ten człowiek ma też pewne zalety, les qualites de ses defauts ${ }^{84}$, jakby można powiedzieć. Otóż mówi on też Ukraińcom to, co myśli $\mathrm{z}$ równą otwartością jak nam, nie zgadzam się z „Czasem”, że jest to często spotykane u Ukraińców, przeciwnie zazwyczaj Ukr[aińcy] są aż nadto dobrymi dyplomatami i na wszelki wypadek mówią zwykle wprost odwrotnie niż myślą.

Kedryn jest szczerym zwolennikiem złagodzenia obecnego stanu zapalnego problemu polsko-ukraińskiego. Na nim spoczywał cały ciężar walki z Palijiwem ${ }^{85}$

zwolennik obozu Panów. (Głos na ławach BB: On nie należy do naszego obozu)”. Por. Sprawozdanie Stenograficzne z 83 posiedzenia Sejmu III kadencji, 9 II 1933, 1. 7-8. Bitner cytował fragment z częściowo skonfiskowanego artykułu A. Bocheńskiego, Czerwienimy się za Was Panowie..., „Bunt Młodych” 1933, nr 35, s. 1.

${ }^{81}$ Iwan Kedryn-Rudnyckyj (1896-1995), polityk i publicysta ukraiński. Żołnierz armii URL, członek UNDO, korespondent Ukraińskiej Reprezentacji Sejmowej (1925-1931), redaktor lwowskiego „Diła”. Po 1945 na emigracji w Austrii i USA, redaktor ukraińskiego pisma emigracyjnego „Swoboda” (1953-1973).

${ }^{82}$ I. Kedryn, Dwie uwagi, „Biuletyn Polsko-Ukraiński”, luty 1933, nr 1(3), s. 9-11.

${ }^{83}$ Z polsko-ruskich zagadnień, „Czas”, 4 III 1933, nr 52, s. 1.

${ }^{84}$ Fr. zalety swych wad.

${ }^{85}$ Dmytro Palijiw (1896-1944), podchorąży w Ukraińskich Strzelcach Siczowych, organizator przewrotu we Lwowie (1918), członek komendy głównej UWO, brał udział w zamachu na J. Piłsudskiego, za co został skazany na 2,5 roku więzienia. Członek UNDO i jego władz (1925-1933), współtwórca OUN (1929), poseł na Sejm RP II kadencji 1928-1930, więzień brzeski (1930-1933), założyciel Frontu Jedności Narodowej (1933-1941), po 1939 współpracował z Niemcami, w 1943 był jednym z ideologów i inicjatorów powstania 14 Dywizji Grenadierów SS Galizien złożonej z Ukraińców. 
podczas ostatniego kongresu Unda ${ }^{86}$. Merytorycznie, jego zdanie zawiera dużo prawdy, ale forma, jak Pan słusznie pisze, jest niemożliwa.

W zeszłym tygodniu byłem u Ks. Metropolity Szeptyckiego ${ }^{87}$, chciałem, aby dał nam wywiad do „Buntu [Młodych]”, ale nie wiem jeszcze, czy to się uda, bo musi wziąć to do sprawdzenia ${ }^{88}$. W bieżącym n[ume]rze „Buntu [Młodych]” jest wywiad z Bartlem ${ }^{89}$, który też bardzo ostro skwalifikował naszą obecną politykę wobec Ukraińców ${ }^{90}$.

Giedroyć pisze mi, że nie mógł niestety skomunikować się z Panem w Warszawie, ale że pewnie zobaczy się z Panem w połowie marca. Może by Pan dał artykuł o książce Chomyszyna ${ }^{91}$ do „Buntu [Młodych]”? Sprawa Danyłyszyna i Biłasa już trochę przebrzmiała, a „Bunt [Młodych]” ma dobry rezonans w prasie i jest dość czytany.

Moja podróż do Niemiec i Warszawy odwleka się, ale zapewne niedługo dojdzie do skutku.

Na razie zasyłam serdeczny uścisk dłoni i wyrazy wys[okiego] szacunku i poważania

[odręcznie: Aleksander Bocheński].

[odręcznie:] Ps. Mój brat ma zamiar napisać wstępny artykuł do „Słowa” o Pana książce ukraińskiej ${ }^{92}$. Niestety w księgarniach lwowskich nie może jej dostać. Proszę o wiadomość gdzie ją zamówić?

[adnotacja ręką S. Łosia: Adolfowi Bocheńskiemu przesłałem książkę 13 II [19]33]

\section{APL, Archiwum Łosiów z Niemiec, sygn. V/1, podt. 1. k. 156-157.}

${ }^{86}$ IV Kongres UNDO odbył się 25-26 marca 1932. Podczas kongresu doszło do starcia pomiędzy opozycyjną, nacjonalistyczną grupą D. Palijiwa a ówczesnym kierownictwem partii reprezentowanym przez Dmytra Łewyckiego. W przeciwieństwie do kierownictwa UNDO, które chciało jednym z celów politycznych uczynić żądanie autonomii terytorialnej w granicach II RP, opozycja uważała, że argument ten może być tylko środkiem taktycznym na forum międzynarodowym. Opozycja bardzo ostro oceniła działalność Ukraińskiej Reprezentacji Parlamentarnej i jej kontakty z rządem na przełomie 1931/1932 r. Ostatecznie komisja redakcyjna rezolucji zjazdowych pominęła postulat autonomii i kwestię potępienia rozmów URP z BBWR. (Por. M. Szumiło, Ukraińska Reprezentacja Parlamentarna $w$ Sejmie i Senacie RP (1928-1939), Warszawa 2007, s. 172-173).

87 Andrzej Szeptycki (1865-1944), greckokatolicki arcybiskup, metropolita lwowski i halicki.

${ }^{88}$ Wywiad ukazał się jako: Rozmowa z J. E. Metropolita Szeptyckim, „Bunt Młodych” kwiecień 1933, nr 39, s. 3.

${ }^{89}$ Kazimierz Bartel (1882-1941), polityk i matematyk. W okresie 1926-1930 pięciokrotny prezes Rady Ministrów II RP. Po 1930 r. wycofał się z życia politycznego i powrócił do pracy naukowej na Politechnice Lwowskiej.

90 Wywiad z profesorem Kazimierzem Bartlem, „Bunt Młodych”, marzec 1933, nr 38, s. 4-5.

${ }^{91}$ Grzegorz Chomyszyn (1867-1945), biskup greckokatolicki, od 1904 biskup diecezji stanisławowskiej. W 1933 r. wydał książkę pt. Problem ukraiński. Napisat dla duchowieństwa i świeckiej inteligencji narodu ukraińskiego Grzegorz Chomyszyn biskup stanisławowski, Warszawa 1933.

92 S. Łoś, O konstruktywną politykę na Rusi Czerwonej, Warszawa 1932. 


\section{Aleksander Bocheński do Stanisława Łosia, 17 V 1933.}

Ponikwa, dnia 17 V 1933

Wielce Szanowny Panie,

Powróciwszy z 4-o tygodniowego pobytu w Czusznowie, zastałem tu artykuł Pana w „Buncie”93, artykuł nadesłany mu łaskawie w „Naszej Przyszłości”94 oraz list, za który bardzo dziękuję. Artykuł w „Buncie” jest doskonały, podkreślam to, tym bardziej że mógłbym wyrazić pewne zastrzeżenia co do innego niedawnego artykułu Sz[anownego] Pana w „Słowie” wil[eńskim] ${ }^{95}$. Artykuł ten nazwałbym nadto bezwzględnym w stosunku do Ukraińców, nie co do meritum, ale co do formy, tam mianowicie, gdzie Pan pisze o instynkcie samobójczym Ukraińców.

Artykuł w „Naszej Przyszłości” nadzwyczaj interesujący. Szkoda, że pojawił się w piśmie, które kumuluje dwie wady, zazwyczaj nieidące w parze: jest mało poważne, a jednak mało poczytne. Artykuł ten jednak powinien, moim zdaniem, ukazać się w osobnej broszurce, aby każdy mógł go sobie kupić, bez konieczności obarczania się tasiemcami „Stańczyka” za cenę 4 zł[otych]. Zwłaszcza świetny jest ten art[ykuł] pod względem publicystycznym. To mnie zawsze najbardziej zajmuje, gdyż ubolewam nad upadkiem prasy prawicowej u nas. Ludzie się boją mieć temperament, a może temperamentu nie mają. Podzieliłbym jednak ten artykuł na dwie części i umieściłbym je w porządku odwrotnym. Najpierw drugą, a potem pierwszą, w której są konkluzje.

Brat mój posłał coś do „Biuletynu [Polsko-Ukraińskiego]”96, gdyż uważał, że artykuł Kedrynia o Rydze jest niemożliwy i nie można go zostawić bez odpowiedzi. Nie wiem, co tam napisał, bo nie było mnie w domu, ale co do mnie, to nie uważam pisma w rodzaju „Biuletynu [Polsko-Ukraińskiego]” za celowe. Są one przeznaczone i dostępne tylko dla małej garstki specjalnie interesujących się tymi sprawami, którzy je i tak znają. Dobre to jest tylko jako forum, gdzie można wszystko pisać, ale zasadniczo pisma finansowane przez rząd to nonsens, o ile mają być niezależne myślowo. Myślę, że raczej korzystna byłaby propaganda w pismach, które nie specjalizują się w sprawie ukr[aińskiej], lecz i poruszają inne także tematy. Chcielibyśmy zrobić taką poważną placówkę z „Buntu [Młodych]”, przynajmniej na uniwersytetach młodzież to czyta, a jak pisał Studnicki naprawdę wpływać można tylko na młodszych od siebie. W tym

93 S. Łoś, Naród Ukraiński a Polska, „Bunt Młodych”, 15 V 1933, nr 41, s. 4-5.

94 S. Łoś, Sytuacja międzynarodowa a Ukraincy haliccy, „Nasza Przyszłość. Wolna Trybuna Zachowawczej Myśli Państwowej”, t. XXX, kwiecień-maj 1933, s. 54-81.

95 S. Łoś, Ukraińska problema, „Słowo”, 31 III 1933, nr 89 (3227), s. 1.

96 A. M. Bocheński, Jeszcze o Traktacie Ryskim, „Biuletyn Polsko-Ukraiński”, maj 1933, nr 4 (6), s. $12-15$. 
marazmie i bezprogramowości kompletnej zarówno B[ezpartyjnego] B[loku] [Współpracy z Rządem], jak i konserwatystów „Bunt [Młodych]” ma za zadanie wytyczenie jasnej linii, bez której nie ma mowy o żadnym solidnym ugrupowaniu politycznym.

Kiedy Pan będzie we Lwowie? Proszę o uprzednią wiadomość, postaram się tam pojechać. Do Niemiec ${ }^{97}$ niestety dotąd nie mogłem się wyrwać.

Łączę wyrazy wys[okiego] szacunku i poważania oraz serdeczny uścisk dłoni

[odr: Aleksander Bocheński].

APL, Archiwum Łosiów z Niemiec, sygn. V/1, podt. 1. k. 178-179.

\section{7}

\section{Aleksander Bocheński do Stanisława Łosia, 21 I 1938.}

Lwów, 21 I 1938 r.

Szanowny Panie,

$\mathrm{W}$ tej chwili dopiero otrzymałem list Sz[anownego] Pana, który mi odesłano z Ponikwy. Echa naszych występów warszawskich były następujące:

Giedroyć mówił mi, że z M[inisterstwa] S[praw] Wojsk[owych] nie ma jeszcze żadnych wiadomości, natomiast, że Grabowski ${ }^{98}$ miał być nader poruszony i zadowolony z naszej wizyty, którą b. pozytywnie ocenia. Natomiast Sawicki ${ }^{99}$ szkodzi jak może.

Bączkowski mówił mi, że nie wierzy jakoby Grabowski miał być zadowolony, gdyż jest uważany za endeka.

Poza tym być może za parę tygodni będziemy mogli odbyć szereg rozmów $z$ gen [erałem] Skwarczyńskim ${ }^{100}$, ale to jeszcze niepewne.

97 Majątek Łosiów, por. przypis nr 33.

98 Witold Grabowski (1898-1966), prawnik, oskarżyciel w procesie brzeskim (1931), minister sprawiedliwości i naczelny prokurator (1936-1939). Członek Klubu 11 Listopada. W czasie II wojny światowej w Brygadzie Karpackiej, po wojnie na emigracji w Etiopii i Wielkiej Brytanii.

99 Jan Sawicki (1890-1950), prawnik, kapitan rezerwy i funkcjonariusz Policji Państwowej i Policji Politycznej. Od 1929 r. pracownik administracji spraw wewnętrznych, od 1933 w MSW. Z dniem 24 III 1937 r. przejął funkcję naczelnika Wydziału Narodowościowego w MSW. Zmarł w Wielkiej Brytanii.

100 Stanisław Skwarczyński (1888-1981), wojskowy, generał brygady WP. Brat Adama Skwarczyńskiego (1886-1934), jednego z głównych ideologów obozu piłsudczykowskiego. Oficer Legionów Polskich, członek POW, od 1918 w WP, w latach 1938-1939 w stanie nieczynnym stał na czele Obozu Zjednoczenia Narodowego. Uczestnik wojny w 1939, po 1945 na emigracji w Londynie. Giedroyc poznał S. Skwarczyńskiego poprzez Maję Prądzyńską (1888-1994), pracownicę redakcji „Buntu Młodych” i „Polityki”, której siostra Anna była żoną Adama Skwarczyńskiego, a po jego śmierci w 1935 r. wyszła za Stanisława Skwarczyńskiego. 
Odsyłam notatki, za które b. dziękuję. Pierwszą część mojej publikacji ${ }^{101}$ oddałem już do przepisywania na maszynie, jak tylko będzie gotowa, Giedroyć prześle ją Panu, dla ew[entualnych] uwag i poprawek. Drugą część zawierającą wskazania rwalne [?], jest „w toku opracowania”. przy sposobności łączę wyrazy prawdz[iwego] poważania

[odręcznie] Al[eksander] Bocheński

APL, Archiwum Łosiów z Niemiec, sygn. 463, k. 5.

Adolf M. Bocheński do Stanisława Łosia, 31 XI 193[8] r.

Ponikwa, dnia 13 XI 193[8]

Wielce Łaskawy Panie!

Brat mój zakomunikował mi list Pana, w którym znalazłem również zapytanie skierowane do siebie. Sądzę, iż analiza sytuacji Rusi Podkarpackiej przeprowadzona przez Pana jest najzupełniej trafna. Twór ten ${ }^{102}$ będzie $\mathrm{z}$ jednej strony narzędziem Niemiec dla szachowania Polski, z drugiej sposobem do silniejszego związania z Niemcami Ukraińców naddnieprzańskich. Nawet w razie utrzymywania się dobrych stosunków między Polską a Niemcami wpływ istnienia autonomicznej Rusi na naszych Ukraińców będzie niewątpliwie bardzo silny. Poza tym doktryna mniejszościowa wypracowana w Niemczech do najdrobniejszych szczegółów i niedługo prawdopodobnie oficjalna narodowego socjalizmu, musi również podziałać na Ukraińców buntująco.

Jedynym sposobem zapobieżenia złu, które z tego wyniknie, byłoby natychmiastowe, radykalne - o wiele radykalniejsze niż dotąd proponowaliśmy - załatwienie sprawy ukraińskiej wewnątrz Polski. Mam na myśli przekształcenie Rzeczpospolitej na państwo dwunarodowe i stanięcie na gruncie propozycji Unda sformułowanych w książce Pełeńskiego ${ }^{103}$. W tym wypadku udałoby się nam prawdopodobnie związać trwale Ukraińców zachodnich z polską racją stanu.

Ponieważ jednak myśl o takim rozwiązaniu jest niewątpliwie marzeniem ściętej głowy, a w razie o ile polityka zachodnioukraińska oprze się zdecydowanie na Rzeszy Niemieckiej, trzeba będzie wszelką akcję w kierunku polepszenia stosun-

101 Prawdopodobnie chodziło o fragment książki Problem polsko-ukraiński w Ziemi Czerwińskiej (Warszawa 1938) opracowanej wspólnie przez Włodzimierza Bączkowskiego, Aleksandra Bocheńskiego i Stanisława Łosia.

102 Autonomię Rusi Zakarpackiej ogłoszono 8 X 1938 r.

103 Z. Poray-Pełeński, Polityka UNDO w świetle autonomicznej deklaracji Centralnego Komitetu UNDO $z$ dnia 7 maja 1938 r., Nasze Słowo 1938. 
ków narodowościowych w Ziemi Czerwieńskiej zawiesić na razie na kołku, więc nie wiem, czy nie byłoby wskazane zakończyć naszą działalność publicystyczną w tej dziedzinie jakimś wspólnym manifestem, czy memoriałem i na razie przestać się tymi sprawami zajmować.

Dopóki bowiem wszystko zależało od dobrej woli Polaków, można było mieć nadzieję - choć słabą - że ich przekonamy. Dziś jednak sytuacja zdecydowanie się psuje, także ze strony Ukraińców, a kroki, które mogłyby ją naprawić, są już wyraźnie nierealne. Czy więc wobec tego nie lepiej odłożyć naszą akcję do czasów, kiedy się okaże, że Rzeczpospolita ostała się w okresie zenitu potęgi niemieckiej?

Gdyby jednak - jak podają gazety - istotnie Kostek Biernacki ${ }^{104}$ został wojewodą lwowskim ${ }^{105}$ - nie należałoby tak postępować, gdyż byłoby to schodzenie z pola walki w chwili nieodpowiedniej. W każdym razie proponowałbym zwołanie nowego zjazdu publicystów zajmujących się tym zagadnieniem o wypracowanie pewnej linii wobec położenia międzynarodowego i wewnętrznego.

Zdaję się, że trochę przesadnie ocenia Pan związki naszej grupy z ulicą Wierzbową. Prawdziwymi jej wyrazicielami są pp. Hrabyk ${ }^{106}$ i Piestrzyński ${ }^{107} \mathrm{z}$ „Kuriera Porannego" ${ }^{108}$. Co do nas, to pochlebiamy sobie, iż nie jesteśmy ani uzależnieni od [pałacu] Bruhlowskiego, ani nawet zbyt pożądani jako zwolennicy.

Łączę wyrazy wysokiego szacunku i poważania

[odręcznie:] Adolf Bocheński

APL, Archiwum Łosiów $z$ Niemiec, sygn. 463, k. 9 r-v

${ }^{104}$ Wacław Kostek Biernacki (1884-1957), pisarz, poeta, pułkownik WP i polityk. Komendant twierdzy brzeskiej (1930), wojewoda nowogródzki (1932) i poleski (1932-1939). Sprawował nadzór nad obozem w Berezie Kartuskiej (1934-1939). Po 1945 r. skazany na karę śmierci zamienioną na 10 lat więzienia.

105 W okresie 31 I 1933-14 IV 1937 wojewodą lwowskim był W. Belina-Prażmowski, od 16 IV 1937 Alfred Biłyk.

106 Klaudiusz Hrabyk (1902-1989), polityk, publicysta. Uczestnik wojny w 1920 r. i III powstania śląskiego. Członek i prezes Młodzieży Wszechpolskiej w Krakowie, prezes OWP w Małopolsce Wschodniej, działacz Związku Młodych Narodowców (1932-1936) i Ruchu Narodowo-Państwowego (1936-1939). W czasie II wojny światowej w Obozie Polski Walczącej, brał udział w Powstaniu Warszawskim. Od 1945 r. na emigracji. Współorganizator Ligii Niepodległości Polski, członek Rady Jedności Narodowej w USA (1953-1955), w 1958 r. powrócił do Kraju, był tajnym współpracownikiem Departamentu I MSW.

107 Ryszard Piestrzyński (1902-1962), dziennikarz i polityk narodowy, redaktor naczelny „Kuriera Porannego" (od 1936), działacz OWP i ZLN, a następnie Związku Młodych Narodowców (1932-1936) i Ruchu Narodowo-Państwowego (1936-1939), poseł na Sejm RP III kadencji (1930-1935), na uchodźstwie członek Rady Narodowej, wydawca i redaktor naczelny „Orła Białego” w Londynie.

108 „Kurier Poranny”, dziennik ukazujący się w Warszawie w 1877-1939, w okresie II RP reprezentował orientację sanacyjną. 


\section{Aleksander Bocheński do Stanisława Łosia, 4 XII 1938.}

\section{Warszawa, 4 XII 1938 r.}

Szanowny i Drogi Panie, rozmawiałem wczoraj z Bączkowskim, który ma następujący projekt Zjazdu w sprawie ukraińskiej [nieczytelny dopisek]. Pragnąłbym, aby Pan, Pioś Borkowski, on sam, mój brat Adolf i ja mieli referaty dość krótkie i poprzednio precyzyjnie uzgodnione oraz koncentrycznie zdążające do pewnych niezbitych konkluzji. Audytorium ma być znacznie szersze jak poprzednio i dyskusja jest przewidziana.

Jeśli idzie o tematy, to Bączk[owski] wziąłby za moją radą: Sowiety wobec nacjonalizmu ukr[aińskiego] (gdzie rozwinie tezę wyzyskiwania Ukr[ainy] przez Sowiety przeciw nam). Adolf miałby: ostatnie zmiany w pol[ityce] zagr[anicznej] w sprawie ukr[aińskiej], chyba że Pan wolałby to opracować samemu. Pozostali mówcy, podzieliliby sobie sytuację wewnętrzną, Pioś mógłby mówić o sytuacji w chwili bieżącej, Pan o najważniejszych błędach w ostatnich latach popełnionych, a ja o możliwościach poprawy sytuacji. Jest to luźny projekt, ale wolę go wcześniej, „współcierpiętnikom" zakomunikować, gdyż na wypadek zgody, trzeba by te referaty wcześniej napisać i uzgodnić.

O ile na Olympie naszym chmurzy się ciągle i od czasu do czasu gromy zdają się mierzyć w naszą stronę, o tyle ostatnio maluczcy zaczynają się nawracać na naszą linię polityczną. Jest to ta część propagandy, która przyniesie nam może mniej cierpkie owoce. Na dzień 8 grudnia otrzymaliśmy dwa zaproszenia: jedno od O[bozu] $\mathrm{N}$ [arodowo] R[adykalnego], które robi w Katowicach wielki zjazd delegatów ${ }^{109}$ dla omówienia programu, drugie od Legi[onu] Młodych i [Związku Polskiej] Mł[odzieży] Demokratycznej, które fuzjonują się razem ${ }^{110}$, przyjmując w stu procentach nasze tezy i dając im tę świeżość, siłę i markę głupoty, jakie zawsze mają programy masówek.

W Grenadzie stronnictwa narodowego też szerzy się zaraza. Młodsze roczniki $z$ Fryczem ${ }^{111}$ na czele idą do nas. Są dopiero w stadium marzeń prometejskich, ale któż z nas przez te choroby dziecinne nie przechodził. [?! - dopisek odręczny]. Skoro raz zerwali z tezą Dmowskiego o konieczności współpracy z Rosją, tłamszenia tego, co się stłamsić nie da, $\mathrm{t}[\mathrm{o}] \mathrm{j}$ [est] ruchu ukr[aińskiego] to muszą trafić prędzej czy później do nas.

Proszę o list do Gedroycia [!] w sprawie zjazdu i łączę serdeczny uścisk dłoni, a dla Pani ucałowanie rąk.

\footnotetext{
1098 XII 1938 w Katowicach odbył się Zjazd Delegatów RNR.

110 W grudniu 1938 część Związku Polskiej Młodzieży Demokratycznej połączyła się z Legionem Młodych, tworząc Legion Młodzieży Polskiej.

111 Karol Stefan Frycz (1910-1942), prawnik, publicysta, współpracownik „Myśli Narodowej”, bliski współpracownik Zygmunta Wasilewskiego, redaktor pisma „Marchołt”, w 1940 aresztowany przez gestapo, po zwolnieniu pracował w RGO w Krakowie, rozstrzelany w Oświęcimiu.
} 
[odręcznie:] Aleksander Bocheński

APL, Archiwum Łosiów $z$ Niemiec, sygn. 463, k. 7 r-v.

\section{Aleksander Bocheński do Stanisława Łosia, 31 XII 1938 r.}

Meyszty, p[oczta] Widze, 31 XII 1938 r.

Szanowny Panie,

dziękuję bardzo za miły list i miłe życzenia. Odpisuję z tak wielkim spóźnieniem, gdyż spędzaliśmy z moją żoną i dziećmi święta w Meysztach u mojej teściowej ${ }^{112}$, gdzie poczta dochodzi rzadko i nieregularnie, zwłaszcza w zimie.

Od tygodnia nie mam wiadomości od Gedroycia [!] i nie wiem w ogóle, co Warszawa robi. Był projekt wydania wspólnej deklaracji w sprawie natężenia stosunków polsko-ukraińskich. Miało to być podpisane przez Legion Młodych, Mł[odzież] Demokratyczną (teraz sfuzjonowane), „Zespół” (poniatowszczycy) ${ }^{113}$, „Siew” (idem) ${ }^{114}$, „Wici” 115 oraz co by się udało z b[yłej] endecji. Niestety niedyskrecja Stachórskiego ${ }^{116}$ zepsuła wszystko. Jednakże rozmowy z lewicą stwierdziły, że z tej strony, gdzie nie natrafiamy na mentalność endecką, jest dużo do zrobienia. Trzeba się liczyć z tym, że organizacje młodo-lewicowe przelicytują nas w dążeniu do zbliżenia z Ukraińcami, co pozycję naszą z jednej strony osłabi, z drugiej wzmocni. Jeśli idzie o nacjonalistów, to miałem ciekawą rozmowę $\mathrm{z}$ Bolesławem Piaseckim ${ }^{117}$ i jego „sztabem” w Katowicach. Mają mentalność endecką, a i działalność Hitlera nie pomaga w propagandzie polityki współdziałania z Ukraińcami.

112 Maria Meysztowicz (1895-1964).

113 Tygodnik „Zespół” (1938-1939) ukazujący się w Warszawie, uważany za stronnictwo utworzone przez działaczy ludowych współpracujących z sanacją i związane z b. ministrem rolnictwa Juliuszem Poniatowskim (1886-1975).

114 Centralny Związek Młodzieży Wiejskiej „Siew”, prorządowa organizacja młodzieży wiejskiej powstała w 1928 w wyniku rozłamu w Centralnym Związku Młodzieży Wiejskiej.

115 Związek Młodzieży Wiejskiej RP „Wici”, niezależna organizacja młodzieży wiejskiej, powstała w 1928 w wyniku rozłamu w Centralnym Związku Młodzieży Wiejskiej.

116 Leon Stachórski (1907-1940), dziennikarz, działacz młodzieżowy i pracownik Oddziału II Sztabu Głównego. W 1934 r. redaktor i korespondent „Dziennika Polskiego” (czeska Orawa) na Litwie, a następnie dziennikarz „Kuriera Porannego” w Warszawie i pracownik PAT. Komendant główny Legionu Młodych (1932-1934). Od 1939 w SZP-ZWZ, zginął w Palmirach.

117 Bolesław Piasecki (1915-1979), prawnik, polityk i publicysta. Początkowo członek OWP i Sekcji Młodych SN, w 1934 jeden ze współtwórców ONR, po rozłamie w ONR (1935) przywódca Ruchu Narodowo-Radykalnego Falanga. W 1934 internowany w Berezie Kartuskiej. Brał udział w wojnie 1939 r., w czasie II wojny światowej założyciel i przywódca tajnej Konfederacji Narodu i Uderzeniowych Batalionów Kadrowych. W 1944 aresztowany przez NKWD, przesłuchiwany przez I. Sierowa. W 1947 stworzył Stowarzyszenie PAX, którego był przewodniczącym do śmierci. 
W tej chwili przynoszą mi list od Gedroycia [!]. Donosi, że deklaracja jest ciągle aktualna, jak tylko miną tak zwane „święta”, prosi o ścisłą dyskrecję. Poza tym nic ciekawego nie donosi.

W czasie pobytu w Meysztach czytałem parę książek: Wojciechowskiego wspomnienia ${ }^{118}$, - dziwnie ciężka lektura. Ten człowiek był jednym z założycieli P[olskiej] P[artii] S[ocjalistycznej] przed wojną, znał lepiej nikt ktokolwiek Piłsudskiego i dosłownie nic ciekawego nie potrafi w swoich pamiętnikach powiedzieć. Poza tym styl okropny. Dobrym stylem, ale też nic nowego nie przynosząc, jest pisana Sukiennickiego „Ewolucja ustroju Rosji Sowieckiej”"119. Same rzeczy, które są dobrze znane $\mathrm{z}$ dzienników, ale każde niemal słowo dowiedzione olbrzymim materiałem cytatów z publikacji bolszewickich. Mimo to lektura ta jest pożyteczna. Pokazuje niesłychanie jasno, na jakie bezdroża wkracza ludzkość, gdy tylko porzuca zdrowy pryncyp demokracji. Z lżejszej literatury czytałem nadzwyczaj ciekawego: Sałowniewicza [!]: „Rosja w obozie koncentracyjnym” ${ }^{20}$ oraz Mackiewicza: „Książka moich rozczarowan'"121. Poczuwałem się, aby z tej ostatniej napisać recenzję: siadłem i napisałem tytuł: Książka moich udręczeń. Więcej nic nie wymyśliłem. Udręczeń, dlatego że Mackiewicz przy swoich niesłychanych zaletach jest głęboko zrusyfikowany. Ciągle Puszkin i Dostojewski, Dostojewski i Puszkin. Przeplata to jednym to innym carem. A szkoda, bo talent bardzo wielki.

Oto wszystko mniej więcej, co mam nowego do napisania. W miesięczniku „Przekrój” ukazała się obszerna recenzja z naszej broszury ${ }^{122}$. Niestety pismo to jest mało znane i mimo uważnej lektury nie potrafiłem dojść do tego, jakich właściwie redakcja jest przekonań ani po co wydaje taki gruby tom artykułów co miesiąc.

Przesyłam wraz z moją żoną ${ }^{123}$ najlepsze życzenia Noworoczne dla Państwa, ręce Pani całuję, a dla Pana załączam serdeczny uścisk dłoni

[odręcznie:] Aleksander Bocheński

APL, Archiwum Łosiów z Niemiec, sygn. 463, k. 8 r-v.

The history of "Bunt Młodych" and "Polityka". Aleksander and Adolf Maria Bocheńskis' letters to Stanisław Łoś (1932-1939).

Brothers Aleksander Bocheński (1904-2001) and Adolf Maria Bocheński (1909-1944) were the closest collaborators of Jerzy Giedroyć in the interwar period. They actively took part in edit-

118 S. Wojciechowski, Moje wspomnienia, t. I, Lwów-Warszawa 1938.

119 W. Sukiennicki, Ewolucja ustroju Związku Socjalistycznych Republik Radzieckich w świetle oficjalnych publikacji władzy radzieckiej, Wilno 1938.

120 I. Sołoniewicz, Rosja w obozie koncentracyjnym, Lwów 1938.

121 S. Mackiewicz, Książka moich rozczarowań, Warszawa 1939.

122 Program imperialny „Polityki”, „Przekrój. Miesięcznik poświęcony sprawom Polski”, październik 1938, nr 2, s. 51-57.

123 Elżbieta Bocheńska z Meysztowiczów. 
ing of "Bunt Młodych" (1931-1937) and "Polityka" (1937-1939) as well as establishing a political line of both magazines. Letters sent to Jan Stanisław Łoś (1890-1974), a conservative and a former diplomat, by them are from the first period of existence of "Bunt Młodych" - the years 1932-1933 and the key period of the interwar period of 1938. The correspondence concerns first and foremost the editorial team attitude towards internal and external policy of the Second Polish Republic including foreign and national policy.

Из истории „Бунта Млодых" и „Политики". Письма Александра и Адольфа Марии Бохеньских к Станиславу Лосю (1932-1939)

Братья Адольф Мария (1909-1944) и Александр (1904-2001) Бохеньские принадлежали к самым близким сотрудниками Ежи Гедройца в межвоенный период. Они принимали активное участие в редактировании „Бунта Млодых” (1931-1937) и „Политики” (1937-1939), а также в создании политической линии обоих журналов. Их письма к Яну Станиславу Лосю (1890-1974), консерватору и бывшему дипломату, относятся к первому периоду существования „Бунта Млодых” - в 1932-1933 гг. и ключевого для межвоенного периода 1938 г. Переписка касается, прежде всего, отношения редакции к внутренней и внешней политике II Речи Посполитой, в том числе к иностранной и национальной. 